\title{
RISIKO KEPUNAHAN KEANEKARAGAMAN HAYATI DI TAMAN NASIONAL GUNUNG MERAPI: TINJAUAN SPASIAL
}

\section{HERO MARHAENTO* \& LIES RAHAYU WIJAYANTI FAIDA}

\author{
Bagian Konservasi Sumberdaya Hutan, Fakultas Kehutanan, Universitas Gadjah Mada \\ Jl. Agro No.1, Bulaksumur, Sleman 55281 \\ *Email: marhaento@ugm.ac.id
}

\begin{abstract}
The Mount Merapi (MM) has a unique landscape and becomes the habitat for mountainous species in the central Java, Indonesia. However, high volcanic activities and massive public pressure on its natural resources have increased the risk of biodiversity extinction in the MM. This study aims to assess the spatial risk of biodiversity extinction in the Mount Merapi National Park (MMNP). The risk analysis has been done by spatially measuring the risk elements i.e. hazard area, element at risk, and vulnerability rate. A Focus Group Discussion has been done to define and to identify components of each risk element. A spatial analysis using ArcGIS 10.1 has been used to measure the risk. The results showed that MMNP have three levels of risks: high risk level area (2185.6 ha, 35. 6\%), moderate risk area (3910.1 ha, 63.6\%) and low risk area (49.8 ha, 0.8\%). The high risk areas were located in Resort Pengelolaan Taman Nasional (RPTN) Dukun in Magelang Distict, RPTN Turi-Pakem in Sleman District, and RPTN Kemalang in Klaten District.
\end{abstract}

Keywords: risk analysis, biodiversity, Mount Merapi National Park, spatial analysis, volcanic.

\section{INTISARI}

Gunung Merapi merupakan habitat dari berbagai spesies khas pegunungan Jawa bagian tengah. Namun demikian, tingginya aktivitas vulkanik Gunung Merapi dan besarnya tekanan masyarakat terhadap kawasan menyebabkan keanekaragaman hayati di sekitar kawasan Gunung Merapi berisiko untuk punah. Penelitian ini bertujuan untuk melakukan analisis spasial risiko kepunahan keanekaragaman hayati di Taman Nasional Gunung Merapi (TNGM). Analisis risiko dilakukan dengan mengukur komponen risiko, yaitu: kerawanan, elemen yang berisiko, dan kerentanan. Identifikasi komponen risiko dilakukan dengan melaksanakan grup diskusi terarah dengan staf Taman Nasional Gunung Merapi. Analisis risiko diukur menggunakan analisis spasial dengan perangkat lunak ArcGIS 10.1. Hasil penelitian menunjukkan bahwa kawasan Taman Nasional Gunung Merapi memiliki kawasan dengan tingkat risiko tinggi seluas 2185.6 ha (35,6\%), risiko sedang seluas 3910,1 ha (63,6\%), dan risiko rendah seluas 49,8 ha (0,8\%). Wilayah yang berisiko tinggi berada di wilayah Resort Pengelolaan Taman Nasional (RPTN) Dukun Kabupaten Magelang, RPTN Turi-Pakem Kabupaten Sleman, dan RPTN Kemalang Kabupaten Klaten.

Kata kunci: analisis risiko, keanekaragaman hayati, Taman Nasional Gunung Merapi, analisis spasial, vulkanik. 


\section{PENDAHULUAN}

Keanekaragaman hayati merupakan sumberdaya vital bagi keberlanjutan hidup umat manusia. Keanekaragaman hayati berperan penting dalam menyediakan kebutuhan barang dan jasa, mengatur proses dan fungsi ekosistem sehingga kehidupan dapat terus berlangsung (Balvanera et al., 2006; Chapin et al., 2000; Loreau et al., 2001). Namun demikian, keanekaragaman hayati saat ini menghadapi risiko kepunahan yang tinggi karena tingginya laju kerusakan lingkungan (Kuussaari et al., 2009). Salah satu upaya untuk menjaga eksistensi keanekaragaman hayati dan mencegahnya dari kepunahan adalah dengan menunjuk dan menetapkan kawasan konservasi (Indrawan et al., 2007), salah satunya adalah taman nasional.

Taman Nasional Gunung Merapi (TNGM) (Gambar 1) merupakan kawasan konservasi yang unik. Selain menyangga gunung api paling aktif di Indonesia, ekosistem hutan di TNGM berfungsi sebagai daerah tangkapan air kawasan Provinsi Jawa Tengah dan Daerah Istimewa Yogyakarta, habitat berbagai spesies flora dan fauna yang dilindungi, kantong berbagai plasma nutfah yang potensial, dan fungsi sosial dan religius (Djuwantoko et al., 2005). Keberadaan Gunung Merapi yang dapat erupsi sewaktu-waktu dan tingginya tekanan masyarakat terhadap kawasan menyebabkan keanekaragaman hayati di TNGM memiliki tingkat kerapuhan yang tinggi (TNGM, 2011).

Salah satu upaya untuk mencegah kepunahan keanekaragaman hayati di TNGM adalah dengan melakukan analisis risiko. Analisis risiko adalah salah satu kajian yang digunakan untuk mendukung pengambilan keputusan (Decision Support Systems) dengan mendasarkan pada analisis kerawanan (hazard), kerentanan (vulnerability), dan jumlah yang berisiko (element at risk) (UNDRO, 1982). Analisis risiko kepunahan keanekaragaman hayati adalah upaya untuk mengukur potensi terjadinya kepunahan keanekaragaman hayati akibat adanya gangguan dari faktor alam maupun non alam.

Penelitian ini bertujuan untuk mengukur secara spasial tingkat risiko kepunahan keanekaragaman hayati di Taman Nasional Gunung Merapi. Tingkatan keaneakaragaman hayati yang menjadi

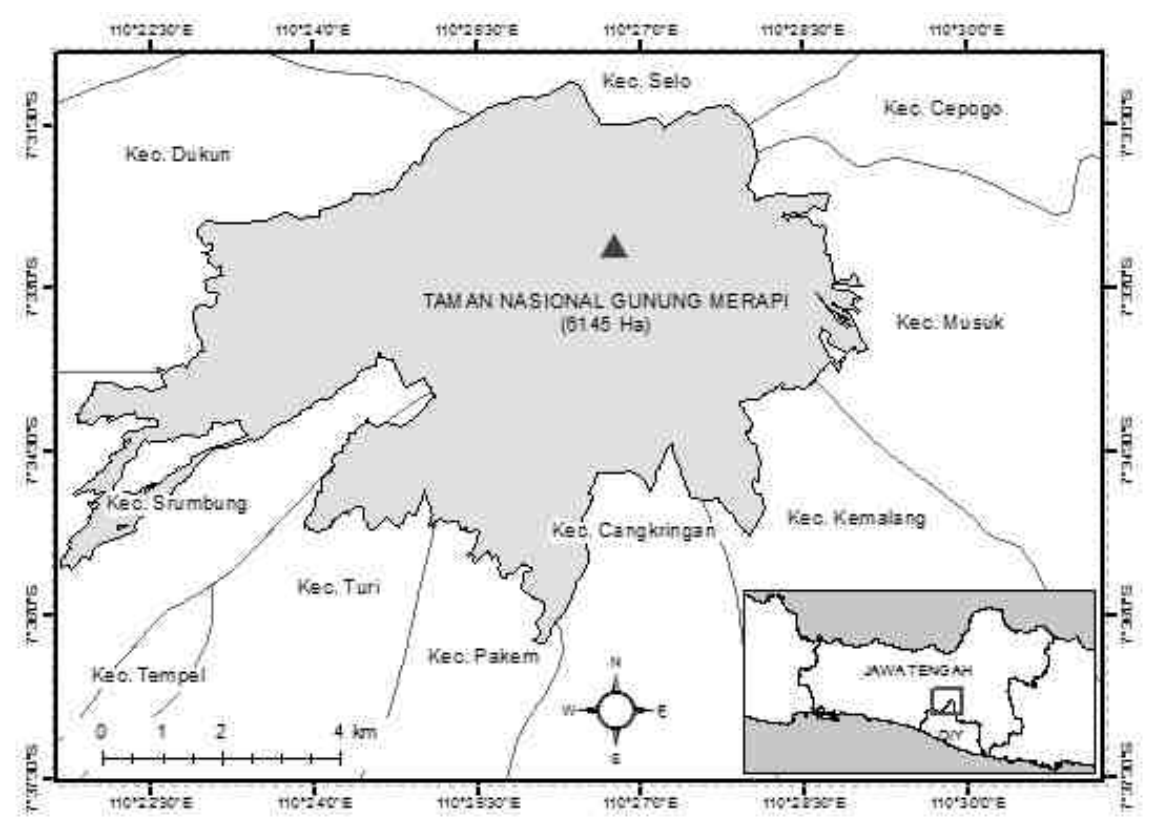

Gambar 1. Peta kawasan Taman Nasional Gunung Merapi 
obyek analisis adalah tingkatan spesies. Manfaat dari penelitian adalah sebagai penyedia informasi awal dalam upaya mitigasi kepunahan keanekaragaman hayati di kawasan TNGM.

\section{BAHAN DAN METODE}

\section{Bahan}

Seluruh bahan yang digunakan dalam penelitian adalah data spasial yang diperoleh dari berbagai sumber, baik yang bersifat intitusional maupun informasi publik (public domain). Perolehan data institusional dilakukan dengan pemeriksaan data dan laporan kegiatan yang dimiliki oleh institusi terkait, sedangkan perolehan data informasi publik dilakukan secara daring dari halaman web penyedia data. Tabel 1 menunjukkan bahan yang digunakan dalam penelitian ini.

\section{Analisis Data}

Terdapat dua tahapan dalam analisis data: 1) mengidentifikasi komponen dalam analisis risiko yaitu nilai kerawanan (hazard), kerentanan (vulnerability), dan elemen yang beresiko (element at risk) dan 2) analisis spasial untuk mengukur komponen risiko dan tingkat risiko.

\section{Mengidentifikasi Komponen Risiko}

Proses identifikasi komponen risiko kepunahan keanekaragaman hayati dilakukan dengan melaksanakan Focuss Group Discussion (FGD) dengan personil Taman Nasional Gunung Merapi (TNGM). Proses FGD dilakukan pada tanggal 19 Oktober 2011 dengan melibatkan 20 orang staf TNGM. FGD dilaksanakan bersamaan dengan kegiatan pembahasan review zonasi TNGM Tahun 2012. Hasil FGD ditunjukkan secara ringkas dalam Tabel 2.

Tabel 1. Bahan dan sumber data yang digunakan dalam penelitian ini

\begin{tabular}{|c|c|c|}
\hline Judul & Skala/resolusi & Sumber \\
\hline $\begin{array}{l}\text { Peta kawasan Taman } \\
\text { Nasional Gunung Merapi }\end{array}$ & $1: 50.000$ & $\begin{array}{l}\text { Balai Pemantapan Kawasan Hutan (BPKH) Wilayah } \\
\text { XI }\end{array}$ \\
\hline $\begin{array}{l}\text { Peta zonasi Taman } \\
\text { Nasional Gunung Merapi }\end{array}$ & $1: 50.000$ & Taman Nasional Gunung Merapi (2012) \\
\hline $\begin{array}{l}\text { Peta Rupa Bumi } \\
\text { Indonesia }\end{array}$ & $1: 25.000$ & Badan Informasi Geospasial \\
\hline $\begin{array}{l}\text { Peta tutupan lahan } \\
\text { TNGM }\end{array}$ & $1: 25.000$ & Taman Nasional Gunung Merapi (2012) \\
\hline $\begin{array}{l}\text { Peta Kawasan Rawan } \\
\text { Bencana (KRB) Gunung } \\
\text { Merapi }\end{array}$ & $1: 50.000$ & Balai Penelitian Teknologi Kegunungapian (BPTK) \\
\hline $\begin{array}{l}\text { Peta sebaran aktivitas } \\
\text { masyarakat di dalam } \\
\text { kawasan TNGM }\end{array}$ & $1: 50.000$ & Taman Nasional Gunung Merapi (2011) \\
\hline $\begin{array}{l}\text { Peta distribusi Elang } \\
\text { Jawa ( Spizaetus bartelsi) } \\
\text { di TNGM }\end{array}$ & $1: 50.000$ & Taman Nasional Gunung Merapi (2011) \\
\hline Peta ketinggian tempat & 30 meter & $\begin{array}{l}\text { ASTER GDEM } \\
\text { (http://gdem.ersdac.jspacesystems.or.jp/) }\end{array}$ \\
\hline Peta kelerengan & 30 meter & ASTER GDEM \\
\hline Peta kerapatan vegetasi & 30 meter & $\begin{array}{l}\text { LANDSAT } 8 \text { path } 120 \text { r ow } 65 \text { liputan } 14 \text { Oktober } \\
2013 \text { (http://earthexplorer.usgs.gov/) }\end{array}$ \\
\hline
\end{tabular}


Tabel 2. Hasil identifikasi komponen risiko kepunahan keanekaragaman hayati di Taman Nasional Gunung Merapi

\begin{tabular}{lll}
\hline \multicolumn{1}{c}{ Komponen risiko } & \multicolumn{1}{c}{ Deskripsi } & Hasil \\
\hline Kerawanan (hazard) & $\begin{array}{l}\text { Kondisi yang disebabkan oleh faktor alam } \\
\text { maupun non alam yang menyebabkan } \\
\text { terjadinya kepunahan keanekaragaman hayati } \\
\text { yang ada di dalam kawasan. }\end{array}$ & $\begin{array}{c}\text { 1. Kerawanan erupsi gunung api } \\
\text { Merapi }\end{array}$ \\
& $\begin{array}{c}\text { 2. Kerawanan oleh aktivitas } \\
\text { masyarakat }\end{array}$ \\
Elemen yang Berisiko & TNGM apabila faktor kerawanan terjadi. & Elang Jawa (Spizaetus bartelsi) \\
(element at risk) & Disepakati bahwa dalam kajian ini tingkatan & \\
& keanekaragaman hayati yang diukur adalah & \\
& tingkatan spesies. Pemilihan obyek & \\
& berdasarkan konsep focal spesies dengan & \\
& kriteria: 1) daya jelajah yang luas (umbrella & \\
& species), 2) spesies khas, 3) status konservasi & \\
tinggi. & Faktor yang mempengaruhi elang Jawa & Pemodelan kesesuaian habitat \\
& mengalami kerusakan atau kepunahan apabila & elang Jawa dilakukan \\
& faktor kerawanan terjadi di TNGM. Faktor & berdasarkan analisis spasial \\
dengan kriteria yang diperoleh \\
kerentanan diukur dengan pemodelan & dari studi literatur. \\
& kesesuaian habitat elang Jawa. &
\end{tabular}

Sumber: Taman Nasional Gunung Merapi (2012)

\section{Analisis Spasial}

Analisis spasial dilaksanakan dengan tujuan : 1) mengubah komponen risiko hasil FGD menjadi data spasial, 2) mengukur tingkat risiko kepunahan keanekaragaman hayati di TNGM. Seluruh analisis spasial dilakukan dengan bantuan perangkat lunak ArcGIS 10.1 student license.

Data spasial kerawanan erupsi Gunung Merapi diperoleh dengan melakukan digitasi peta Kawasan Rawan Bencana (KRB) Gunung Merapi dari Badan Nasional Penanggulangan Bencana (BNPB). Terdapat 4 kelas dalam peta KRB, yaitu : KRB III, KRB II, KRB I dan non-KRB yang masing-masing menunjukkan tingkat kerawanan Gunung Merapi. Hasil digitasi kelas kerawanan selanjutnya dilakukan re-klasifikasi menjadi 3 kelas, yaitu: kelas kerawanan tinggi untuk KRB III, kerawanan sedang untuk KRB II, dan kerawanan rendah untuk KRB I dan non-KRB.

Data spasial kerawanan akibat interaksi masyarakat dalam kawasan TNGM diperoleh dengan melakukan analisis penyangga (buffer) sejauh $500 \mathrm{~m}$ dan $1 \mathrm{~km}$ dari titik lokasi interaksi masyarakat yang diperoleh dari TNGM (2012). Pemberian buffer 500 $m$ bertujuan untuk mendefinisikan batas area dengan intensitas masyarakat tinggi, sementara buffer $1 \mathrm{~km}$ bertujuan untuk mendefinisikan batas area dengan intensitas masyarakat sedang. Kawasan di luar buffer $1 \mathrm{~km}$ kemudian didefinisikan sebagai area dengan intensitas masyarakat rendah. Metode skoring dan tumpang susun dilakukan terhadap kedua peta tematik tersebut dengan pemberian nilai 10 untuk kelas rendah, nilai 50 untuk kelas sedang, dan nilai 100 untuk kelas tinggi. Hasil tumpang susun kedua peta tematik kerawanan tersebut selanjutnya dilakukan re-klasifikasi dengan ketentuan kerawanan tinggi untuk total skor 140-200, kerawanan sedang untuk total skor 80-139, dan kerawanan rendah untuk total skor 20-79.

Sama dengan analisis kerawanan, analisis kerentanan elang Jawa ditentukan berdasarkan pemberian skor dan operasi tumpang susun kriteria-kriteria kesesuaian habitat elang Jawa. Penentuan kriteria kesesuaian habitat elang Jawa 
dilakukan berdasarkan studi oleh Setiadi et al. (2000), Nijman et al. (2003), dan Cahyana (2009), yaitu: penutupan tajuk, ketinggian tempat, kelerengan, dan penggunaan lahan. Masing-masing faktor tersebut dipetakan menjadi 3 kelas: tinggi, sedang, dan rendah sesuai dengan tingkat kerentanannya. Pemberian skor dilakukan dengan derajat nilai 10 untuk kelas rendah, nilai 50 untuk kelas sedang, dan nilai 100 untuk kelas tinggi. Tabel 3 menunjukkan skor dari masing-masing kelas pada tiap kriteria kesesuaian habitat elang Jawa. Hasil kerentanan dibagi menjadi 3 kelas berdasarkan pembagian total skor secara proporsional, yaitu: kerentanan tinggi (skor 280-400), kerentanan sedang (skor 160-279), dan kerentanan rendah (skor 40-159).

\section{Analisis Risiko}

Analisis risiko (R) merupakan fungsi dari kerawanan (hazard, H), kerentanan (vulnerability, V) dan elemen yang berisiko (element at risk, EaR) yang hubungannya dapat dijelaskan dalam formula berikut :

$$
\mathrm{R}=\mathrm{H} * \mathrm{~V} * \mathrm{EaR}
$$

Berdasarkan formula hubungan tersebut, tingkat risiko berbanding lurus dengan kerawanan dan kerentanan obyek yg berisiko. Dalam analisis spasial, proses ini dilakukan dengan operasi tumpangsusun seluruh komponen risiko. Proses pemberian skor dan tumpangsusun kembali dilakukan dengan ketentuan yang sama seperti proses sebelumnya. Hasil dari analisis ini adalah 3 kelas risiko, yaitu: risiko tinggi, risiko sedang, dan risiko rendah.

\section{HASIL DAN PEMBAHASAN}

\section{Tingkat Kerawanan}

Hasil dari peta kerawanan menunjukkan bahwa 5.605,68 ha $(91,22 \%)$ kawasan Taman Nasional Gunung Merapi masuk dalam KRB III (rawan tinggi), 283,68 ha (4,17\%) masuk KRB II (rawan sedang), dan 256,11 ha (4,61\%) masuk wilayah yang KRB I dan non-KRB (rawan rendah). Tingkat kerawanan akibat aktivitas masyarakat dalam kawasan menunjukkan bahwa kawasan TNGM yang sudah diakses oleh masyarakat dengan intensitas tinggi adalah seluas $2.368,4$ ha $(38,5 \%)$, sedangkan dengan intensitas rendah adalah seluas $3.777,1$ ha

Tabel 3. Skor masing-masing kelas pada tiap faktor kelas kerentanan elang Jawa

\begin{tabular}{cccr}
\hline \multirow{2}{*}{ Kriteria } & Kelas & Indikator & Skor \\
\hline \multirow{2}{*}{ Penutupan Tajuk } & Tinggi & NDVI* $\geqslant 0.3$ & 100 \\
& Sedang & $0.1 \leqslant$ NDVI $<0.3$ & 50 \\
Tinggi tempat & Rendah & NDVI $<0.1$ & 10 \\
& Tinggi & $500-1000 \mathrm{~m} \mathrm{dpl}$ & 100 \\
& Sedang & $1000-2000 \mathrm{~m} \mathrm{dpl}$ & 50 \\
Kelerengan & Rendah & $<500 \mathrm{~m} \mathrm{dpl} \mathrm{dan} 2000 \mathrm{~m}<$ & 10 \\
& Tinggi & $25 \% \leqslant$ lereng $<45 \%$ & 100 \\
& Sedang & $8 \%-<25 \%$ dan $45 \% \leqslant$ & 50 \\
Penggunaan lahan & Rendah & $0-<8 \%$ & 10 \\
& Tinggi & Hutan alam dan campur & 100 \\
& Sedang & Hutan sekunder dan sejenis & 50 \\
& Rendah & Lahan budidaya & 10 \\
\hline
\end{tabular}

*NDVI = Normalized Difference Vegetation Index, diukur dengan menggunakan fasilitas raster math pada ArcGIS 10.1 dengan memanfaatkan saluran biru dan saluran infra merah dekat pada citra LANDSAT 8 
(61,5\%). Gabungan kedua faktor kerawanan tersebut menunjukkan bahwa sebagian besar wilayah Taman Nasional Gunung Merapi adalah rawan tinggi dengan luas $5.864,2$ ha $(95,4 \%), 268,3$ ha $(4,4 \%)$ rawan sedang, dan 13,0 ha $(0,2 \%)$ adalah rawan rendah. Sebaran wilayah tingkat kerawanan di TNGM tersaji pada Gambar 2.

\section{Tingkat Kerentanan}

Hasil dari analisis kerentanan di Taman Nasional Gunung Merapi menunjukkan bahwa 2.282,5 ha (37,2\%) adalah kerentanan tinggi, 2.435,1 ha $(39,6 \%)$ adalah kerentanan sedang, dan $1.427,9$ ha $(23,2 \%)$ adalah kerentanan rendah. Distribusi spasial tingkat kerentanan di TN Gunung Merapi tersaji pada Gambar 3.

\section{Tingkat Risiko}

Hasil dari analisis risiko kepunahan keanekaragaman hayati menunjukkan bahwa $2.185,6$ ha $(35,6 \%)$ kawasan berisiko tinggi, 3.910,1 ha $(63,6 \%)$ kawasan berisiko sedang, dan 49,8 ha (0,8\%) adalah kawasan berisiko rendah. Kawasan yang berisiko tinggi terutama terdapat di RPTN Dukun, RPTN Turi-Pakem dan RPTN Kemalang, kawasan berisiko sedang di RPTN Selo dan RPTN Musuk-Cepogo dan kawasan berisiko rendah merupakan sebagian kecil dari wilayah RPTN Musuk-Cepogo. Distribusi spasial tingkat risiko kepunahan keanekaragaman hayati di TN Gunung Merapi tersaji pada Gambar 4.

\section{Analisis Risiko dan Zonasi}

Analisis risiko kepunahan keanekaragaman hayati adalah upaya untuk mengukur potensi terjadinya kepunahan keanekaragaman hayati akibat adanya gangguan dari faktor alam maupun non alam. Penelitian ini mengembangkan skema pemetaan risiko bencana dari UNDRO (1982) dengan memasukkan unsur keanekaragaman hayati sebagai faktor yang berisiko dalam konsep yang dikembangkan oleh Moore (1956).

Dari hasil analisis risiko menunjukkan bahwa kawasan TNGM yang memiliki tingkat risiko kepunahan keanekaragaman hayati tinggi berada di wilayah kelola RPTN Dukun, RPTN Turi-Pakem, dan RPTN Kemalang. Wilayah tersebut memiliki tingkat ancaman yang tinggi terutama dari aspek tekanan masyarakat terhadap kawasan TNGM. Pada kawasan tersebut, jalur-jalur akses masuk berupa jalan setapak maupun jalur kendaraan bermotor

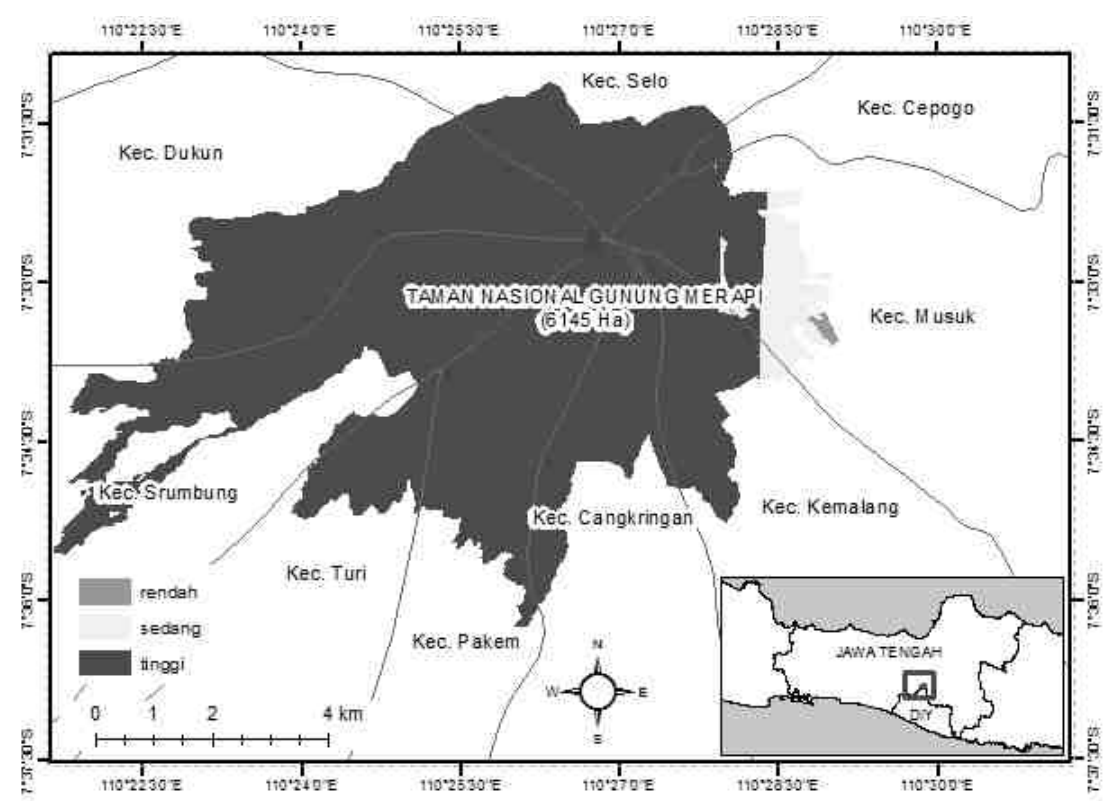

Gambar 2. Peta tingkat kerawanan di Taman Nasional Gunung Merapi 


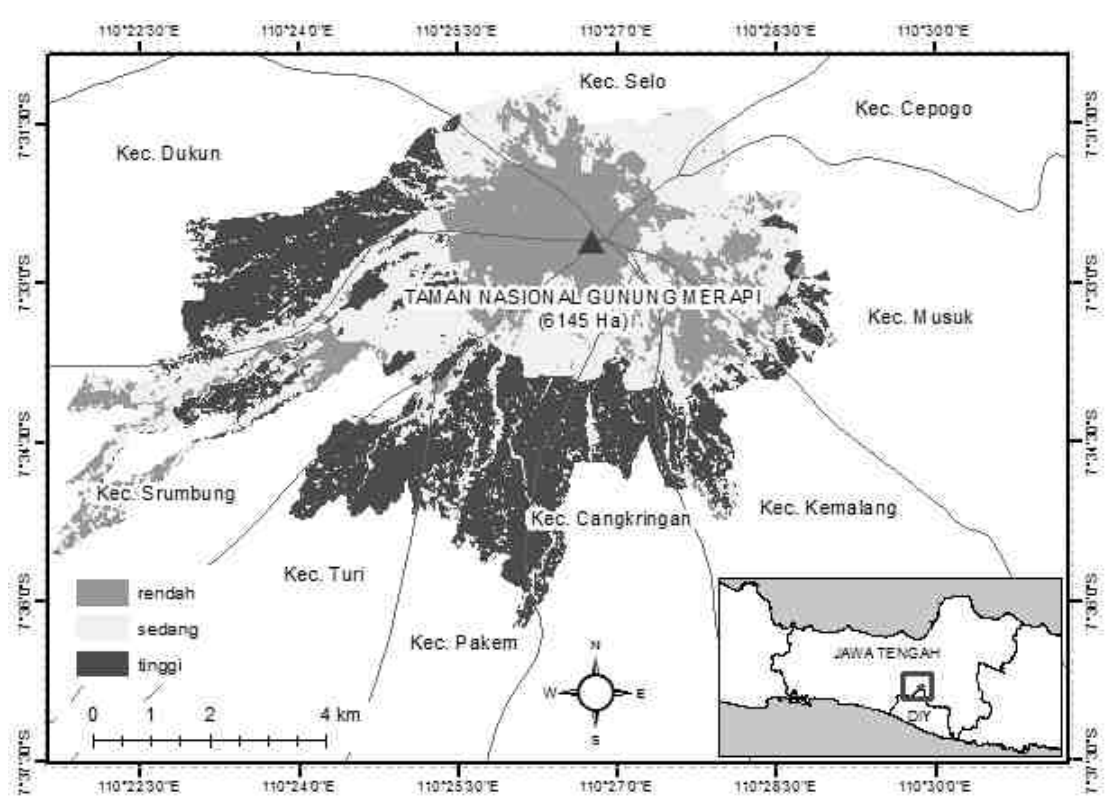

Gambar 3. Peta tingkat kerentanan di Taman Nasional Gunung Merapi

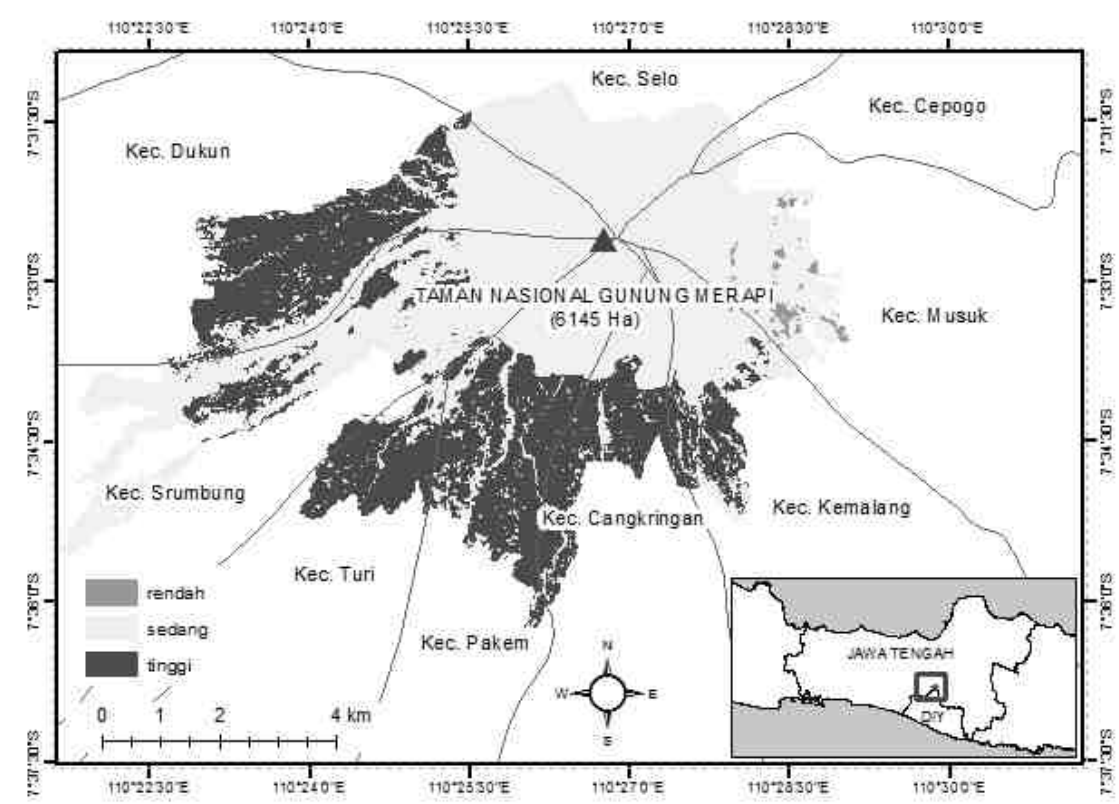

Gambar 4. Peta tingkat risiko kepunahan keanekaragaman hayati di Taman Nasional Gunung Merapi

dapat dengan mudah dijumpai. Menurut TNGM (2011), masyarakat masuk ke dalam hutan kawasan TNGM untuk merumput dan mencari daun untuk pakan ternak yang dilakukan setiap hari dengan intensitas satu sampai 2 kali dalam sehari. Masyarakat masuk ke dalam hutan sejauh $1 \mathrm{~km}$ hingga $2 \mathrm{~km}$ dari desanya dengan kendaraan bermotor dan berjalan kaki. Tingginya aktivitas masyarakat tersebut menjadi ancaman bagi keanekaragaman hayati yang ada di kawasan TNGM. Tingginya ancaman oleh aktivitas masyarakat terhadap kelestarian keanekaragaman hayati juga dikemukakan oleh Hansen et al. (2001), Díaz et al. (2006), dan Kuussaari et al. (2009).

Faktor alam erupsi Gunung Merapi juga menjadi ancaman bagi kelestarian keanekaragaman hayati di 
TNGM. Aktivitas vulkanik Gunung Merapi terjadi dalam siklus pendek (2-5 tahun) dan siklus menengah (5-7 tahun). Kejadian erupsi Gunung Merapi cukup besar yang terjadi pada tahun 2010 telah menimbulkan kerugian ekologis yang cukup besar dengan luasnya kerusakan hutan akibat terjangan awan panas dan material Gunung Merapi. Marhaento dan Kurnia (2015) menyebutkan bahwa erupsi pada tahun 2010 menyebabkan 38,2\% kawasan TNGM mengalami kerusakan sedang hingga berat. Lokasi yang mengalami kerusakan berat tersebut adalah di RPTN Pakem-Turi, RPTN Cangkringan, RPTN Srumbung, RPTN Dukun, RPTN Sawangan, RPTN Selo, dan RPTN Kemalang. Wilayah-wilayah tersebut juga merupakan kawasan dengan tingkat risiko kepunahan keanekaragaman hayati tinggi. Hal ini sesuai dengan Novacek dan Cleland (2001) yang menyebutkan bahwa bencana alam merupakan salah satu faktor utama yang mengancam eksistensi keanekaragaman hayati di suatu wilayah.

Elang Jawa merupakan salah satu jenis satwa liar yang termasuk kategori genting (endangered) menurut IUCN, termasuk dalam daftar appendix II CITES, termasuk satwa liar yang dilindungi menurut Keppres No.4 tahun 1993, dan merupakan satwa khas TNGM. Walaupun penelitian ini menggunakan satu spesies sebagai elemen yang terisiko, namun jangkauan habitat dari elang Jawa juga merupakan habitat penting bagi spesies yang lain (umbrella species). Sehingga risiko kerusakan dan kepunahan terhadap jenis tersebut juga merupakan risiko bagi spesies lainnya (Indrawan et al., 2007).

Penataan zonasi merupakan salah satu upaya yang dilakukan pengelola taman nasional untuk melindungi potensi keanekaragaman hayati yang dimiliki. Zonasi merupakan pengaturan ruang-ruang di taman nasional yang memperhatikan aspek-aspek ekologis, sosial, ekonomi, dan budaya masyarakat (Permenhut No. 56 tahun 2006). Zonasi TNGM yang sudah ditetapkan pada tahun 2012 cukup mampu merepresentasikan kebutuhan perlindungan terhadap potensi keanekaragaman hayati yang ada. Lokasilokasi yang termasuk dalam kawasan berisiko kepunahan tinggi sudah ditunjuk sebagai zona inti. Namun demikian, pengelolaan zona inti saat ini lebih difokuskan pada aspek pengamanan dari aktivitas masyarakat dan tidak ada rencana kelola terkait ancaman erupsi Gunung Merapi. Untuk itu, diperlukan adanya rencana kontingensi dalam pengelolaan zona inti untuk menghindarkan kematian dan kepunahan keanekaragaman hayati akibat bencana erupsi Gunung Merapi. Salah satu upaya yang dapat dilakukan adalah dengan membuat kantong-kantong pelarian satwa liar (refugee) termasuk jalur (koridor) pelariannya (Dowie, 2011). Lokasi kantong-kantong satwa dapat dipilih pada habitat yang sesuai dan memiliki tingkat risiko kepunahan keanekaragaman hayati rendah. Blok hutan Gunung Bibi dan blok hutan Turgo merupakan dua lokasi yang direkomendasikan sebagai lokasi pelarian satwa liar. Di lokasi tersebut juga dapat ditunjuk sebagai lokasi pengembangan tanaman koleksi TNGM yang bernilai konservasi tinggi untuk menjaga eksistensi keanekaragaman hayati di TNGM.

\section{KESIMPULAN}

Hasil tinjauan spasial risiko kepunahan keanekaragaman hayati di TNGM menunjukkan bahwa $2.185,6$ ha $(35,6 \%)$ kawasan berisiko tinggi yang berlokasi di RPTN Dukun, RPTN Turi-Pakem, dan RPTN Kemalang, 3.910,1 ha $(63,6 \%)$ adalah kawasan risiko sedang yang berlokasi di RPTN Selo dan RPTN Musuk-Cepogo, dan 49,8 ha (0,8\%) risiko rendah yang berlokasi di sebagian kecil dari wilayah 
RPTN Musuk-Cepogo. Informasi spasial tingkat risiko kepunahan keanekaragaman hayati ini selanjutnya dapat diintegrasikan dalam proses penataan kawasan TNGM dalam rangka melindungi eksistensi keanekaragaman hayati yang ada di dalam kawasan TNGM.

\section{UCAPAN TERIMAKASIH}

Penelitian ini terlaksana atas bantuan program Hibah Kompetisi Berbasis Institusi (PHKI), untuk itu penulis mengucapkan banyak terimakasih kepada pengelola hibah PHKI di tingkat Universitas Gadjah Mada dan Fakultas Kehutanan UGM. Selain itu, penulis juga mengucapkan terimakasih kepada Totok Wahyu Wibowo dari Fakultas Geografi UGM atas bantuannya dalam mengolah data spasial dan Asep N. Kurnia dari Kantor Balai Taman Nasional Gunung Merapi (TNGM) atas bantuan penyediaan data dan laporan kegiatan di TNGM.

\section{DAFTAR PUSTAKA}

Balvanera P, Pfisterer AB, Buchmann N, He J, Nakashizuka T, Raffaelli D, \& Schmid B. 2006. Quantifying the evidence for biodiversity effects on ecosystem functioning and services. Ecology Letters 9(10), 1146-1156.

Cahyana AN. 2009. Pemodelan Spasial Habitat Elang Jawa (Spizaetus Bartelsi Stresemann, 1924), Elang Hitam (Ictinaetus Malayanus Temminck, 1822), dan Elang-Ular Bido (Spilornis cheela Latham, 1790) dengan Menggunakan Sistem Informasi Geografis di Kabupaten Ciamis Bagian Utara. Skripsi (Tidak dipublikasikan). Departemen Konservasi Sumberdaya Hutan dan Ekowisata, Fakultas Kehutanan Institut Pertanian Bogor

Chapin FS, Zavaleta ES, Eviner VT, Naylor RL, Vitousek PM, Reynolds HL, Hooper DU, Lavorel S, Sala OE, Hobbie SE, Mack MC, \& Díaz S. 2000. Consequences of changing biodiversity. Nature 405, 234-242.
Díaz S, Fargione J, Chapin III FS, \& Tilman D. 2006. Biodiversity loss threatens human well-being. PLoS biology 4(8), e277.

Djuwantoko, Purnomo DW, \& Laksono FY. 2005. Taman Nasional Gunung Merapi : Peluang dan tantangan realisasi Taman Nasional di Pulau Jawa bagian tengah. Seminar Nasional : Menuju Taman Nasional Gunung Lawu. DOI: http://lib.ugm.ac.id/digitasi/upload/2723_MU.11 110010.pdf

Dowie M. 2011. Conservation refugees: the hundred-year conflict between global conservation and native peoples. MIT Press.

Hansen AJ, Neilson RP, Dale VH, Flather CH, Iverson LR, Currie DJ, \& Bartlein PJ. 2001. Global change in forests: Responses of species, communities, and biomes interactions between climate change and land use are projected to cause large shifts in biodiversity. BioScience 51(9), 765-779.

Indrawan M, Primarck RB, \& Suprijatna J. 2007. Biologi Konservasi (edisi revisi). Yayasan Obor Indonesia, Jakarta.

Kuussaari M, Bommarco R, Heikkinen RK, Helm A, Krauss J, Lindborg R, Öckinger E, Pärtel M, Pino J, Rodà F, Stefanescu C, Teder T, Zobel M, \& Steffan-Dewenter I. 2009. Extinction debt: A challenge for biodiversity conservation. Trends in Ecology and Evolution 24(10), 564-571.

Loreau M, Naeem S, Inchausti P, Bengtsson J, Grime JP, Hector A, Hooper DU, Huston MA, Raffaelli D, Schmid B, Tilman D, \& Wardle DA. 2001. Biodiversity and ecosystem functioning: current knowledge and future challenges. Science 294, 804-808.

Marhaento H \& Kurnia A. 2015. Refleksi 5 tahun paska erupsi Gunung Merapi 2010: Menaksir kerugian ekologis di kawasan Taman Nasional Gunung Merapi. Geoplanning: Journal of Geomatics and Planning 2(2), 69-81.

Moore H. 1956. Towards a theory of disaster. American Sociological Review 21, 734-737.

Nijman V \& van Balen S. (Bas). 2003. Wandering stars: age-related habitat use and dispersal of Javan Hawk-eagles (Spizaetus bartelsi). Journal fur Ornithologie 144, 451-458.

Novacek MJ \& Cleland EE. 2001. The current biodiversity extinction event: scenarios for mitigation and recovery. Proceedings of the National Academy of Sciences 98(10), 5466-5470. 
Setiadi AP, Rakhman Z, Nurwatha PF, Muchtar M, \& Raharjaningtrah W. 2000. Status, Distribusi, Populasi, Ekologi dan Konservasi Elang Jawa Spizaetus bartelsi, Stressemann 1924 di Jawa Barat Bagian Selatan. Laporan Akhir BP/FFI/Birdlife International/YPAL-HIMBIO UNPAD, Bandung

Taman Nasional Gunung Merapi. 2011. Laporan Restorasi Ekosistem TN Gunung Merapi Paska Erupsi 2010. Yogyakarta. Tidak dipublikasikan.

Taman Nasional Gunung Merapi. 2012. Laporan Review Zonasi Taman Nasional Gunung Merapi. Yogyakarta. Tidak dipublikasikan.

UNDRO. 1982. Natural disasters and vulnerability analysis. Report of Expert Group Meeting. Office of The United Nations Disaster Relief Coordinator, Geneva. 